\title{
Exacerbation of collagen induced arthritis by Fc $\gamma$ receptor targeted collagen peptide due to enhanced inflammatory chemokine and cytokine production
}

\author{
This article was published in the following Dove Press journal: \\ Biologics:Targets and Therapy \\ II April 2012 \\ Number of times this article has been viewed
}

\author{
Eszter Szarka $1 *$ \\ Zsuzsa Neer ${ }^{*}$ \\ Péter Balogh² \\ Monika Ádori' \\ Adrienn Angyal' \\ József Prechl ${ }^{3}$ \\ Endre Kiss ${ }^{1,3}$ \\ Dorottya Kövesdi' \\ Gabriella Sármay' \\ 'Department of Immunology, Eötvös \\ Loránd University, I I I7 Budapest, \\ ${ }^{2}$ Department of Immunology and \\ Biotechnology, University of Pécs, \\ Pécs, ${ }^{3}$ Immunology Research Group \\ of the Hungarian Academy of Science \\ at Eötvös Loránd University, II I 7 \\ Budapest, Hungary \\ *These authors contributed equally \\ to this work
}

\begin{abstract}
Antibodies specific for bovine type II collagen (CII) and Fc $\gamma$ receptors play a major role in collagen-induced arthritis (CIA), a mouse model of rheumatoid arthritis (RA). Our aim was to clarify the mechanism of immune complex-mediated inflammation and modulation of the disease. CII pre-immunized DBA/1 mice were intravenously boosted with extravidin coupled biotinylated monomeric CII-peptide epitope (ARGLTGRPGDA) and its complexes with biotinylated Fc $\gamma$ RII/III specific single chain Fv (scFv) fragment. Disease scores were monitored, antibody titers and cytokines were determined by ELISA, and binding of complexes was detected by flow cytometry and immune histochemistry. Cytokine and chemokine secretion was monitored by protein profiler microarray. When intravenously administered into collagen-primed DBA/1 mice, both CII-peptide and its complex with $2.4 \mathrm{G} 2 \mathrm{scFv}$ significantly accelerated CIA and increased the severity of the disease, whereas the monomeric peptide and monomeric 2.4G2 scFv had no effect. FcyRII/III targeted CII-peptide complexes bound to marginal zone macrophages and dendritic cells, and significantly elevated the synthesis of peptide-specific IgG2a. Furthermore, CII-peptide containing complexes augmented the in vivo secretion of cytokines, including IL-10, IL-12, IL-17, IL-23, and chemokines (CXCL13, MIP-1, MIP-2). These data indicate that complexes formed by the CII-peptide epitope aggravate CIA by inducing the secretion of chemokines and the IL-12/23 family of pro-inflammatory cytokines. Taken together, these results suggest that the in vivo emerging immune complexes formed with autoantigen(s) may trigger the IL-12/23 dependent pathways, escalating the inflammation in RA. Thus blockade of these cytokines may be beneficial to downregulate immune complex-induced inflammation in autoimmune arthritis.
\end{abstract}

Keywords: collagen-induced arthritis, Fc gamma receptor, immune complex, inflammation, targeting

\section{Introduction}

Due to its similar immunological characteristics involving high levels of auto-antibodies and collagen specific T-cells, collagen-induced arthritis (CIA) obtained by immunizing DBA/1 mice with bovine type II collagen (CII), is a widely used model of human rheumatoid arthritis (RA). ${ }^{1}$ In this arthritis model anti-CII antibodies are regarded as important factors in the development of arthritis, as the transfer of sera from diseased mice can induce CIA in healthy DBA/1 recipients. ${ }^{2}$ Furthermore, anti-CII IgG can mediate arthritis by engaging the activating $\mathrm{Fc}$ gamma receptors $(\mathrm{Fc} \gamma \mathrm{R})$, indicating that pathogenic immune complexes play a fundamental role in the onset of disease. ${ }^{3,4}$ 
IgG-containing immune complexes that can bind to $\mathrm{Fc} \gamma \mathrm{R}$ are crucial players in the pathogenesis of arthritis, as they have a regulatory role in both the central and the effector phase of CIA. ${ }^{5}$ In mice, four subtypes of IgG receptors (Fc $\gamma R I$, Fc $\gamma R I I b, ~ F c \gamma R I I I$ and Fc $\gamma$ RIV) have been identified. ${ }^{6,7}$

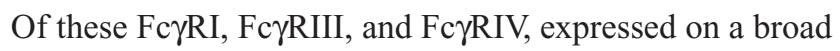
variety of leukocytes including neutrophils, macrophages, NK cells, and dendritic cells, transmit stimulatory signals through an immunoreceptor tyrosine-based activation motif (ITAM). ${ }^{6,8-10}$ In contrast, Fc $\gamma$ RIIb is regarded as an inhibitory receptor and contains an immunoreceptor tyrosine-based inhibition motif (ITIM). ${ }^{11-13} \mathrm{Fc} \gamma \mathrm{RIIb}$ is expressed on B-cells, macrophages, dendritic cells, and mast cells. Fc $\gamma$ RIIb deficiency renders normally resistant strains of mice susceptible to several antibody- or immune complex-dependent models of autoimmunity. ${ }^{14-16}$ The balance between activating and inhibitory Fc $\gamma \mathrm{R}$ has a decisive role in the outcome of

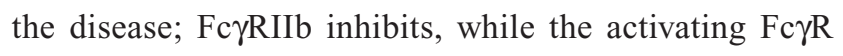
augments CIA. ${ }^{7,17,18}$ Moreover, FcR $\gamma$ chain-deficient mice were completely resistant to antibody-mediated arthritis. ${ }^{3}$ Although FcyRI and Fc $\gamma$ RIII themselves were shown to be dispensable for the development of destructive arthritis, the common FcR $\gamma$ chain was nevertheless required for the process, indicating that Fc $\gamma \mathrm{RIV}$, the new member of the $\gamma$ chain associated receptor family may play a role in the effector phase of CIA. ${ }^{19}$

Cytokines may influence the expression of FcyR by several mechanisms; for example IFN $\gamma$ directly upregulates activating receptor expression on macrophages and polymorphonuclear cells, while IL-17 enhances cartilage destruction by increasing the local amount of Fc $\gamma R$-bearing neutrophils in immune complex-mediated arthritis. ${ }^{20}$ Subsequently, the crosslinking of activating Fc $\gamma$ RIII by immune complexes triggers the release of pro-inflammatory cytokines, TNF $\alpha$ and IL-1 from macrophages ${ }^{21}$ may thus establish an amplifying loop, ultimately resulting in severe inflammation and tissue damage in RA.

An arthritis-related immunodominant triple-helical B-cell epitope (between amino acid positions 359-369) in CII has been described that was also recognized by sera from RA patients but not by sera from other donors; moreover, the combined transfer of two mouse monoclonal antibodies specific for the triple helical CII epitope induced arthritis in the non-susceptible BALB/c mice. ${ }^{22,23}$ We applied the biotinylated CII-peptide corresponding to the monomeric CII sequence (ARGLTGRPGDA) coupled to extravidin. Our aim was to investigate how Fc $\gamma$ RII/III targeting of this CII peptide by single chain $\mathrm{Fv}$ fragment ( $\mathrm{scFv}$ ) of the monoclonal antibody, 2.4G2 may modulate the immunopathogenesis of CIA. Previously we and others have shown that antibody response against model antigens can be substantially improved by Fc $\gamma \mathrm{RII} / \mathrm{III}$ targeting. ${ }^{24,25}$ Extravidin-linked molecular constructs of the biotinylated CII-peptide and its complex with mono-biotinylated $2.4 \mathrm{G} 2 \mathrm{scFv}$ were injected intravenously into CII pre-immunized DBA/1 mice, and the in vivo effect on several parameters of CIA, including arthritic score, antibody response to CII and CII-peptide, as well as cytokine/chemokine secretion were monitored. The results indicate that the exposure of collagen preimmunized DBA/1 mice to CII-peptide-containing complexes results in a significant elevation of IL-12/23 family inflammatory mediator secretion, ultimately leading to the acceleration and increased severity of CIA.

\section{Materials and methods Reagents and antibodies}

The 2.4G2 cell clone (IgG2a) was kindly provided by the Department of Immunology, University Hospital Utrecht, The Netherlands. BirA was purchased from Avidity LLC (Aurora, CO), bovine type II collagen and complete Freund adjuvant containing $5 \mathrm{mg} / \mathrm{mL}$ heat killed mycobacteria tuberculosis were purchased from Chondrex Inc (Redmond, WA), rat anti-mouse CD45R (B220)-PerCP/Cy5.5 and hamster anti-mouse CD11c-Alexa 647 from AbD Serotec (Oxford, UK). F4/80 rat IgG2b Alexa Fluor 647 conjugated antibodies were from eBioscience Ltd, Hatfield, UK. PE-conjugated rat anti-mouse CR1/2 (7G6 clone) mAb was purchased from Soft Flow Inc (Pécs, Hungary). Marginal zone macrophage marker (macrophage receptor with collagenous structure [MARCO], clone IBL-12 ${ }^{26}$ ) and the Cy3-labelled goat anti-rat IgG were purified and labelled at the Department of Immunology and Biotechnology, University of Pecs (Pecs, Hungary). Biotinylated CII-peptide (ARGLTGRPGDA) was obtained from Mimotopes Pty Ltd, Melbourne, Australia, and also synthesized by Dr Anna Magyar, Research Group of Peptide Chemistry, Hungarian Academy of Sciences at Eötvös Loránd University of Sciences. For biotinylation, sulpho-NHS-long chain-biotin was used to provide flexibility for the peptide. All other reagents were purchased from Sigma-Aldrich (Budapest, Hungary).

\section{Mice}

DBA/1 mice were obtained from Charles River Laboratories (Budapest, Hungary), CD16 and CD64 KO mice were a kind gift from Dr Attila Mocsai (Semmelweis University, Budapest, Hungary). ${ }^{27,28}$ Mice aged 8-16 weeks were used 
for all experiments. Animals were kept on a standard diet with tap water ad libitum. All animal studies were approved by the local research ethics committee.

\section{Induction and evaluation of collagen- induced arthritis (CIA)}

CII was dissolved in $0.1 \mathrm{M}$ acetic acid at $2 \mathrm{mg} / \mathrm{mL}$ concentration. Six-week old female DBA/1 mice were immunized subcutaneously at the base of the tail with $100 \mu \mathrm{g}$ CII emulsified in Complete Freund Adjuvant (CFA). At days 30, 45 and 70 after immunization the "complex" group received intravenous injection of preformed complexes of $60 \mu \mathrm{g}$ biotinylated $2.4 \mathrm{G} 2 \mathrm{scFv}, 2.6 \mu \mathrm{g}$ biotinylated collagen peptide (CII-peptide) and $60 \mu$ g extravidin (2:2:1 molar ratio) per animal. The CII-peptide tetramer group was injected with $2.6 \mu \mathrm{g}$ biotinylated CII-peptide (ARGLTGRPGDA) mixed with $30 \mu \mathrm{g}$ Extravidin per animal (4:1 molar ratio). The $2.4 \mathrm{G} 2 \mathrm{scFv}$ tetramer group was given $60 \mu \mathrm{g}$ biotinylated $2.4 \mathrm{G} 2 \mathrm{scFv}$ and $30 \mu \mathrm{g}$ extravidin per animal (4:1 molar ratio). The tetramer CII-peptide, $\mathrm{scFv}$ and the mixed complexes were produced by the stepwise addition of extravidin to achieve the required molar ratio.

Supplementary file 1 shows the composition of the extravidin-bound $2.4 \mathrm{G} 2 \mathrm{scFv}$, CII-peptide and CII-peptide $-2.4 \mathrm{G} 2 \mathrm{scFv}$ mixed complexes resolved by nonreducing sodium dodecyl sulfate polyacrylamide gel electrophoresis. According to the calculated molecular masses, most of the extravidin-bound scFv appeared as dimers and tetramers, while in the extravadin-bound CII-peptide sample we observed a smear between 55-70 kDa, showing three distinct lines, probably corresponding to different numbers of extravidin-bound peptide molecules. The CII-peptide-scFv complexes appeared as smears around $130 \mathrm{kDa}$ (probably corresponding to a mixed complex). Since one molecule of extravidin theoretically binds 4 biotinylated molecules, for simplicity, we call extravidin-linked CII-peptide or scFv constructs "tetramers," while the mixed constructs are referred to as "complexes."

The control group of mice received intravenous injections of the buffer only. Blood samples were collected at days 35 , 55 and 70 after the CIA induction.

Dates of onset of the disease after immunization were recorded for individual mice. The progress of CIA was evaluated visually, scored on a graded scale of 1-3 for each paw. ${ }^{29}$ An arthritic index of the disease was calculated, based upon the visual appearance of a paw. Each limb was graded 0-3, representing increased joint swelling, erythema, and visible joint distortion. Changes in the number of affected limbs and the arthritic scores for each limb were recorded twice a week. Arthritic scores were combined to give a global arthritic score of a maximum of 12 for each mouse.

\section{Preparation of the single-chain Fv antibody}

$2.4 \mathrm{G} 2 \mathrm{scFv}$ was prepared and purified as previously described. ${ }^{24,30} 2.4 \mathrm{G} 2$ recognizes both Fc $\gamma \mathrm{RII}$ (CD32) and Fc $\gamma$ RIII (CD16) ${ }^{31}$ Protein constructs also containing a peptide tag recognized by the E. coli biotinyl ligase BirA were biotinylated with the enzyme according to the manufacturer's instructions. ${ }^{32,33}$ The functional integrity of $2.4 \mathrm{G} 2 \mathrm{scFv}$ was tested on mouse spleen cells. The $\mathrm{scFv}$ bound to B-cells ${ }^{27}$ and was able to inhibit $\mathrm{Ca}^{2+}$ mobilization when co-crosslinked with $\mathrm{BCR}^{34}$ (Supplementary file 2).

\section{Flow cytometry}

The in vitro binding of biotinylated $2.4 \mathrm{G} 2 \mathrm{scFv}$ or biotinylated CII-peptide attached to extravidin-fluorescein isothiocyanate (FITC), or the extravidin-FITC coupled mixed complexes of the two molecules was analyzed in spleen cell suspension. Spleens from the CIA-induced DBA/1 mice were removed and treated with $2 \mathrm{mg} / \mathrm{mL}$ collagenase $\mathrm{D}$ (Roche) according to the manufacturer's instructions: $5 \times 10^{5}$ cells were labeled with preformed complexes of biotinylated $2.4 \mathrm{G} 2 \mathrm{scFv}$ and/or biotinylated CII-peptide and extravidin-FITC for 15 minutes on ice. Cells were simultaneously stained with anti-mouse CD45R (B220)- PerCP/Cy5.5 for detection of B-cells, antiCD11c hamster IgG labeled with Alexa 647 for dendritic cells, and F4/80 rat IgG2b Alexa 647 for macrophages, respectively. Samples were analyzed by FACS-Calibur flow cytometer (Becton-Dickinson, Franklin Lakes, NJ) and the data were evaluated with FCS Express 3 software (De Novo Software, Los Angeles, CA).

\section{Immunofluorescent detection of the in vivo localization of extravidin-FITC containing complexes}

Spleens of mice initially immunized with collagen, then injected intravenously with $2.4 \mathrm{G} 2 \mathrm{scFv}$-CII-peptideextravidin-FITC complex, 2.4G2 scFv-extravidin-FITC or CII-peptide-extravidin-FITC were taken out 15 minutes after the intravenous injection and mounted in cryostat-embedding medium (Killik; Bio-Optica, Milan, Italy) and then stored at $-80^{\circ} \mathrm{C}$ until processed. Frozen sections of $8 \mathrm{~mm}$ thickness were cut, collected and fixed in ice-cold acetone for $10 \mathrm{~min}-$ utes and then blocked with $5 \%$ bovine serum albumin (BSA) in phosphate buffered saline (PBS) for 30 minutes at room 
temperature in a wet chamber. Sections were incubated with antibodies specific for the marginal zone macrophage marker [MARCO, clone IBL-12 ${ }^{26}$ ] and developed using Cy3-labelled goat anti-rat IgG; and with complement receptor (CR1/2) specific antibodies. Fluorescent images were captured using a ColorView CCD camera mounted onto an Olympus BX61 fluorescent microscope. The fluorescent signals were sequentially recorded using a 460-490 nm band-pass excitation filter and 515-550 nm band-pass filter for FITC, and a $530-550 \mathrm{~nm}$ band-pass excitation filter with a $590 \mathrm{~nm}$ longpass filter for $\mathrm{Cy} 3$, respectively, at the resolution of $300 \mathrm{dpi}$. After acquisition the two images were merged using Adobe Photoshop with screen mode.

\section{Detection of Cll- and Cll-peptide specific antibodies}

CII- and CII-peptide-specific IgG titer in sera of immunized mice were determined by indirect ELISA. To detect CII specific antibodies, plates were coated with $5 \mu \mathrm{g} / \mathrm{mL}$ bovine collagen, and then blocked with 1\% BSA in PBS. Serum samples were diluted 1:200, and then a four-fold dilution series was used for the measurements. For detection of CII-peptide-specific antibodies, biotinylated CII-peptide ( $1 \mu \mathrm{g} / \mathrm{mL})$ was added to NeutrAvidin $(5 \mu \mathrm{g} / \mathrm{mL})$ pre-coated plates (Thermo Scientific, Rockford, IL). The plates were blocked with buffer containing $40 \mathrm{mM}$ TRIS-HCl, $150 \mathrm{mM}$ $\mathrm{NaCl}, 0.5 \% \mathrm{BSA}$ and $0.1 \%$ Tween. Serum samples were used in 1:100 dilutions, and then 5-fold dilution series were used for the measurements. The plates were washed and developed by HRP-conjugated anti-mouse IgG or anti-mouse IgG2a followed by adding TMB peroxidase substrate solution. Finally, the reaction was stopped and the optical density was measured at $450 \mathrm{~nm}$ with wavelength correction at $620 \mathrm{~nm}$ by ELISA reader (Thermo Electron, Multiscan Ex). Endpoint titers were calculated.

\section{Evaluation of the level of cytokines and chemokines in mouse sera by a protein profiler array}

For the detection of cytokines and chemokines in mouse sera, the Mouse Cytokine Array, Panel A (ARY006, R\&D Systems, Minneapolis, MN) was used, the estimation of the cytokines and chemokines in sera samples was carried out following the manufacturer's protocol. Pooled sera samples from each group of mice (collected at day 70, 2 hours after the intravenous injection of $2.4 \mathrm{G} 2 \mathrm{scFv}-\mathrm{CII}$-peptide complexes or tetramer constructs of the scFv and CIIpeptide, respectively) were added to the membranes, and after incubation with the detection antibody the membranes were developed with streptavidin-HRP (Thermo Scientific, Rockford, IL), followed by the chemiluminescent reagent, and then exposed to X-ray film. Pixel densities were analyzed in each spot of the array by the GenePix Pro 6.0 program (Molecular Devices, Sunnyvale, CA), and average values of duplicate spots were compared.

\section{Detection of cytokines in the supernatants of cultured spleen cells}

In ex vivo experiments the spleen cells of collagen-immunized DBA/1 mice were tested after the animals received two intravenous injections of extravidin plus $2.4 \mathrm{G} 2 \mathrm{scFv}$ or CII-peptide, or the extravidin-coupled complexes of the two molecules, respectively. One week after the last injection mice were sacrificed from each group, and their spleen cells were cultured in the presence of one tenth of the in vivo given quantity of complex, CII-peptide or scFv tetramer. After 24 hours, 48 hours and 72 hours the culture supernatants were tested for cytokine production.

To study the effect of $2.4 \mathrm{G} 2 \mathrm{scFv}$ on cytokine secretion in vitro, spleen cells $\left(2.5 \times 10^{6}\right.$ cells $\left./ \mathrm{mL}\right)$ from $\mathrm{C} 57 \mathrm{BL} / 6$ wild type, CD16 KO, or CD64 $\mathrm{KO}$ mice were cultured in RPMI-1640 medium or on streptavidin pre-coated, biotinylated $2.4 \mathrm{G} 2 \mathrm{scFv}$ coated immunoplates (Millipore) for 72 hours at $37^{\circ} \mathrm{C}$.

The amounts of cytokines in the culture supernatants were measured using the Quantikine ELISA kits according to the manufacturer's instruction (R\&D Systems, Minneapolis, USA). Protein amount was calculated by the formula obtained from standards.

\section{Statistical analysis}

Statistical differences between disease scores of various experimental groups of mice were assessed by pairwise comparisons of relevant groups using permutation tests. Briefly, values from the groups to be compared were randomly reassigned to two groups and the difference between the group means was calculated. Distribution of 10000 randomizations was drawn and the two-tailed $P$ value corresponding to the real sample assignments was determined. The arithmetic mean of 50 such $P$ values was accepted as the probability of $\alpha$-error. Values of $P<0.05$ were considered significant and were indicated as follows: $*, P<0.05$; **, $P<0.01$; $* * *, P<0.001$. We used this test for two reasons: (1) the distribution of the tested variables is neither known nor can be reliably estimated, so a nonparametric test was the choice, and (2) standard nonparametric tests for comparing two 
groups, such as the Mann-Whitney U test, are less sensitive when the sample number is limited, while permutation tests are robust from this point of view.

Median values of experimental groups in ELISA were compared with a Kruskal-Wallis test. Differences between groups were considered significant for $P<0.05$. The data were analysed by using GraphPad Prism version 4.00 for Windows (Graphpad Software Inc, La Jolla CA).

\section{Results}

Complexes of 2.4G2 scFv and Cll-peptide modulate the kinetics and severity of $\mathrm{CIA}$

To study the effect of extravidin-coupled complexes of CII-peptide on CIA, DBA/1 mice first received a single subcutaneous injection of bovine type II collagen in CFA on day 0 , which was followed by the intravenous injection of extravidin-linked constructs at day 28. Arthritic scores of mice were monitored. Four weeks after the initial immunization with CII in CFA the animals did not show any phenotypic signs of arthritis. Injecting the mice at day 28 with extravidinlinked CII-peptide (peptide tetramer) or 2.4G2 scFv (scFv tetramer) elevated the arthritic score values by five days after the injection, while the scores remained between 0 and 2.5 in the control, untreated group, receiving buffer only. On day 10 (40 days after the initial immunization) we observed a significant difference between the groups receiving buffer and those injected with the extravidin-coupled mixed complexes of CII-peptide and $2.4 \mathrm{G} 2 \mathrm{scFv}$ or with the CII-peptide and the $2.4 \mathrm{G} 2 \mathrm{scFv}$ tetramers, respectively, while mice injected with the monomeric peptide and monomeric $2.4 \mathrm{G} 2 \mathrm{scFv}$ showed similar scores to the control group. At day 55, ten days after the second injection with the same constructs the differences between the control and the complex- or the CII-peptide tetramer-treated groups were still significant, indicating an aggravated disease state (Figure 1).

\section{Enhanced Cll-peptide-specific antibody titers in sera of collagen immunized and then 2.4G2 scFv-Cll-peptide complex-treated mice}

We compared the antibody titers in sera of collagen-primed mice 5 days after the first intravenous injection of $2.4 \mathrm{G} 2 \mathrm{scFv}$ CII-peptide complexes, CII-peptide tetramer and 2.4G2 scFv tetramer, respectively, and then 10 days after the second injection with the same constructs; using either collagen coat or biotinylated CII-peptide as capture antigen. Administration of CII-peptide tetramers slightly elevated the collagen specific antibody titer on day 5 as compared to the non-treated animals, while the other treatments had no effect on anti-collagen IgG production. 10 days after the second injection (55 days after the initial immunization) no significant differences were observed between the anti-collagen titers of different groups (Figure 2, left panel). On the contrary, the CII-peptide specific IgG titers were significantly higher at both time points in mice treated with FcyRII/III targeted CII-peptide as compared to all other groups. However, CII-peptide specific IgG was also detected in the peptide- or scFv tetramer-treated mice and at lower level in the collagen primed control as well. The CII-peptide specific IgG2a titers showed a similar distribution (Figure 2 right panels).

\section{In vitro binding and in vivo localization of $2.4 \mathrm{G} 2 \mathrm{scFv}-\mathrm{Cll}$-peptide complexes}

To investigate which cell types bind the complexes and the tetramer constructs, flow cytometry and immunohistochemistry experiments were performed. In vitro binding of $2.4 \mathrm{G} 2 \mathrm{scFv}$ in complex with CII-peptide, tetramers of CII-peptide or $2.4 \mathrm{G} 2 \mathrm{scFv}$ (both preformed with extravidinFITC) to spleen cells of suboptimally collagen immunized mice was tested. Flow cytometric analysis revealed that approximately $47 \%$ of B220 positive cells (B-cells), $41 \%$ of CD11c positive cells (dendritic cells, DC), and 60\% of F4/80 positive cells were also positive for $2.4 \mathrm{G} 2 \mathrm{scFv}-\mathrm{CII}$-peptide complexes. The F4/80 molecule is expressed selectively on subpopulations of myeloid cells, including macrophages and DCs. ${ }^{35}$ The $2.4 \mathrm{G} 2 \mathrm{scFv}$ tetramer bound at similar ratios to all populations: to $40 \%$ of B-cells, $36 \%$ of dendritic cells, and $55 \%$ of F4/80 positive cells, while the CII-peptide tetramer specifically bound to about $10 \%$ of B-cells, and surprisingly, to $30 \%$ of dendritic cells (DC), and $40 \%$ of macrophages (Figure 3). Spleen cells of non-immunized mice did not bind CII-peptide tetramers (data not shown). These data indicate that CII-peptide may bind to Fc $\gamma \mathrm{R}$ on DC and macrophages via peptide-specific IgG.

In vivo localization of the intravenously injected extravidin-FITC containing complexes and tetramers in spleen sections of suboptimally collagen immunized mice was visualized by double immunofluorescence. Fifteen minutes after the intravenous injections the $2.4 \mathrm{G} 2 \mathrm{scFv}-\mathrm{CII}-$ peptide complexes were observed mainly in the marginal zone (MZ) area in co-localization with the $\mathrm{MZ}$ macrophage marker, MARCO. Occasional follicular co-staining was also seen with some of the CR1/CR2 positive, most probably dendritic cells. Co-localization with IgM positive or IgD positive B-cells could not be observed (data not shown). 
Day 35

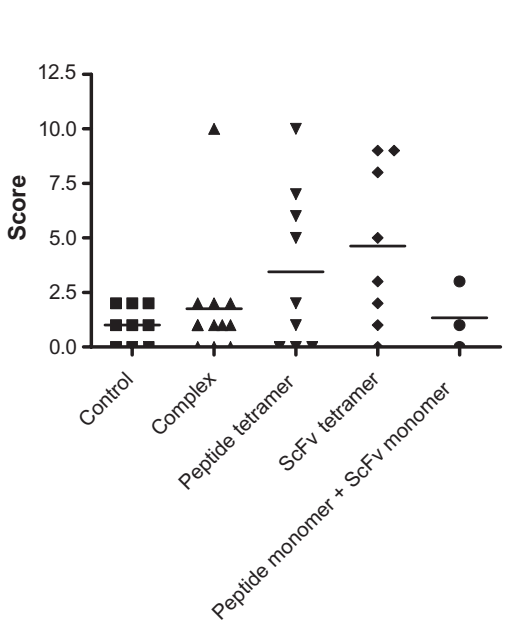

Day 40

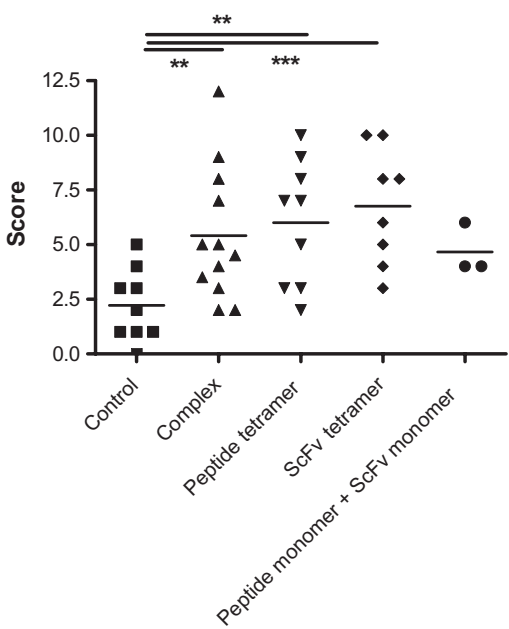

Day 55

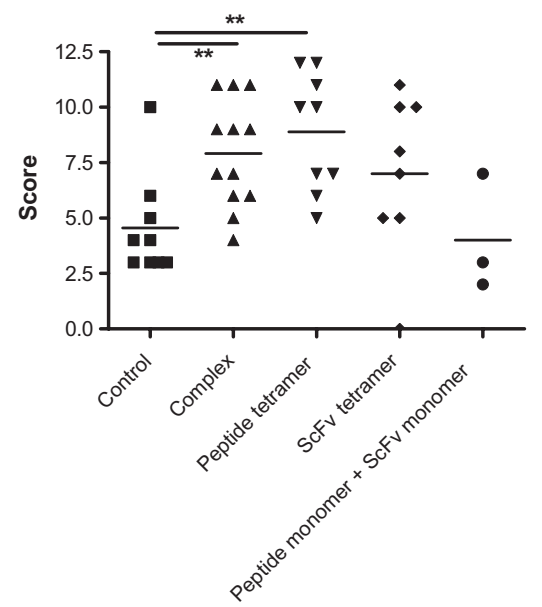

Figure I Extravidin-linked complexes of biotinylated Cll-peptide and biotinylated 2.4G2 scFv, Cll-peptide tetramers and 2.4G2 scFv tetramers elevate disease scores in CIA of DBA/I mice.

Notes: All mice received a single subcutaneous injection of CII in CFA on day zero, then they were intravenously injected with the complexes, Cll-peptide or 2.4G2 scFv tetramers, and with the mixture of monomeric Cll-peptide and $2.4 \mathrm{G} 2 \mathrm{scFv}$, respectively, on day 30 and day 45 . The control group received buffer injection only. Arthritic scores were registered every 2-3 days. Score values of the four groups of mice are shown on day 35 , day 40 , and day 55 . Cumulated data of two independent experiments. Significant differences between experimental groups are shown, $* P<0.05$, $* * P<0.01$.

Abbreviations: CII, bovine type II collagen; CIA, collagen-induced arthritis; scFv, single chain Fv fragment.

The $2.4 \mathrm{G} 2 \mathrm{scFv}$ tetramers stained fewer cells and showed much less co-staining but a similar distribution, while CIIpeptide tetramers stained scattered cells mainly in the T-zone of the spleen (Figure 4). Collectively these data indicate that the constructs containing $2.4 \mathrm{G} 2 \mathrm{scFv}$ may bind to a fraction of B-cells in the spleen. Shortly after intravenous injection they are mostly located in marginal zone macrophages, and to a lesser extent are associated with dendritic cells in the non-follicular compartment of the white pulp. Binding of CIIpeptide tetramers was also detected in this latter population.
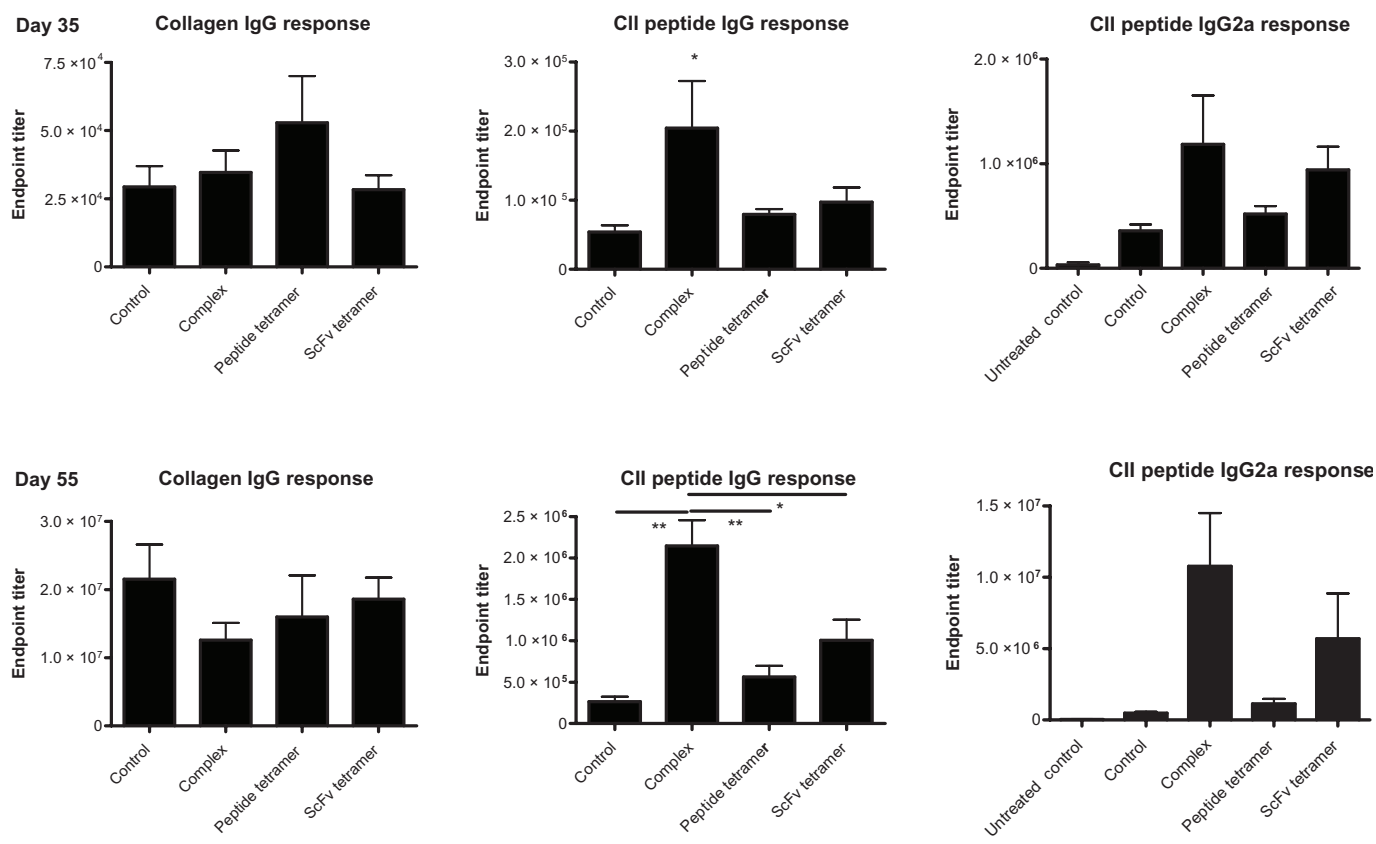

Figure 2 Collagen-specific and Cll-peptide specific lgG titers in sera of mice treated with $2.4 \mathrm{G} 2$ scFv and Cll-peptide containing constructs.

Notes: Serum samples were taken on day 35, 5 days after the first injection (upper panel); and on day 55, 10 days after the second injection (lower panel). Mice were treated as described at Figure I. Cll and Cll-peptide specific IgG and CIl-peptide specific IgG2a production in the four experimental groups was compared by ELISA, endpoint titers were calculated. Significant differences between experimental groups are shown, $* P<0.05, * * p<0.0$ I.

Abbreviations: CII, bovine type II collagen; ELISA, enzyme-linked immunosorbent assay; scFv, single chain Fv fragment. 


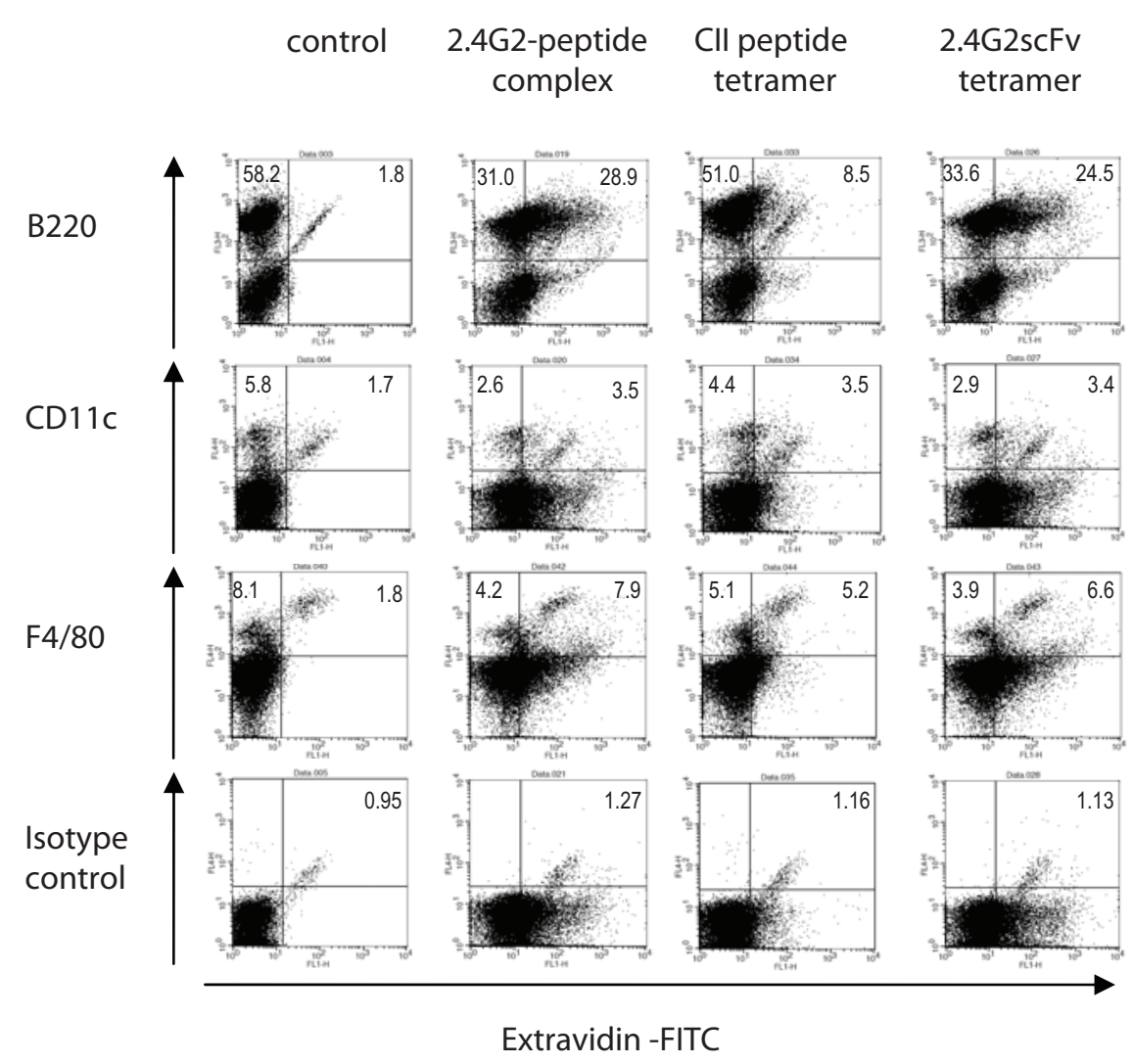

Figure 3 In vitro binding of $2.4 \mathrm{G} 2 \mathrm{scFv}-\mathrm{Cll}$-peptide complexes, Cll-peptide and $2.4 \mathrm{G} 2 \mathrm{scFv}$ 'tetramer's to spleen cell subsets.

Notes: The binding was visualized by adding extravidin-FITC to the biotinylated molecules at I:4 molar ratio to preform complexes or tetramers, respectively. Spleen cell subsets were identified by anti-mouse CD45R (B220)-PerCP/Cy5.5 (B-cells), anti-mouse CDI Ic-Alexa 647 (dendritic cells) or anti-mouse F4/80-Alexa 647 (macrophages) monoclonal antibodies, respectively. Extravidin-FITC was also added to control samples. Alexa 647 labeled rat lgG2b staining is shown as the isotype control. The numbers represent the percentages of positive cells in a quadrant. A representative sample out of three independent experiments is shown.

Abbreviations: CII, bovine type II collagen; FITC, fluorescein isothiocyanate; scFv, single chain Fv fragment.

\section{Induction of cytokine/chemokine secretion by FcyRII/III targeting}

To investigate whether the complexes and tetramers exert their effect on CIA via inducing cytokine/chemokine production, in vitro cultures of spleen cells from collagen immunized and complex- or tetramer-treated mice were tested. Additionally to the in vivo injection of the constructs, spleen cells of mice were cultured in the presence of $2.4 \mathrm{G} 2$ scFv-CII-peptide complexes or the tetramer peptide and $2.4 \mathrm{G} 2 \mathrm{scFv}$, respectively, and then the culture supernatants were tested after 24, 48 and 72 hours. A time-dependent induction of TNF $\alpha$, IL-17, IFN $\gamma$, and IL-10 secretion was detected in supernatants of cells cultured with the $2.4 \mathrm{G} 2 \mathrm{scFv}$-CII-peptide complexes. In contrast, $\mathrm{scFv}$ tetramers triggered a much lower amount of cytokine release, and the CII-peptide tetramers did not induce ex vivo cytokine production (Figure 5). The TH2 cytokine, IL-4, was not detected in any of the culture supernatants (data not shown). These data indicate that the $2.4 \mathrm{G} 2 \mathrm{scFv}$ CII-peptide complexes are able to stimulate the release of pro-inflammatory cytokines, including IL-17 that is critical for arthritis; and also suggest that CII-peptide targeted to FcyRII/III is more efficient at stimulating cytokine release as compared to Fc $\gamma \mathrm{RII} / \mathrm{III}$ crosslinking alone.

2.4G2 scFv binds to both FcyRII and FcyRIII positive cells. To investigate whether the activating receptor, FcyRIII is indeed responsible for the cytokine release, we compared the $2.4 \mathrm{G} 2 \mathrm{scFv}$ tetramer-induced TNF $\alpha$ and IL-17 production in spleen cell cultures of wild type (C57BL/6), CD16 KO, and CD64 KO mice. The results show that CD64 KO mice were able to produce, while $\mathrm{CD} 16 \mathrm{KO}$ animals failed to secrete these cytokines upon interaction with the $2.4 \mathrm{G} 2$ tetramers, indicating that Fc $\gamma \mathrm{RIII}$ is indispensable for the effect, which cannot be compensated by Fc $\gamma$ RI and Fc $\gamma$ RII (Figure 6).

To investigate whether $2.4 \mathrm{G} 2 \mathrm{scFv}$-CII-peptide complexes and the tetramer constructs are able to induce cytokine/ chemokine synthesis in vivo, collagen pre-immunized mice received a third intravenous injection of complexes or tetramers 70 days post-primary immunization, and then 2 hours after the booster, serum samples were collected. Cytokine/chemokine protein profiler microarray analysis was 
2.4G2-CII peptide complex

\section{CR1/CR2}
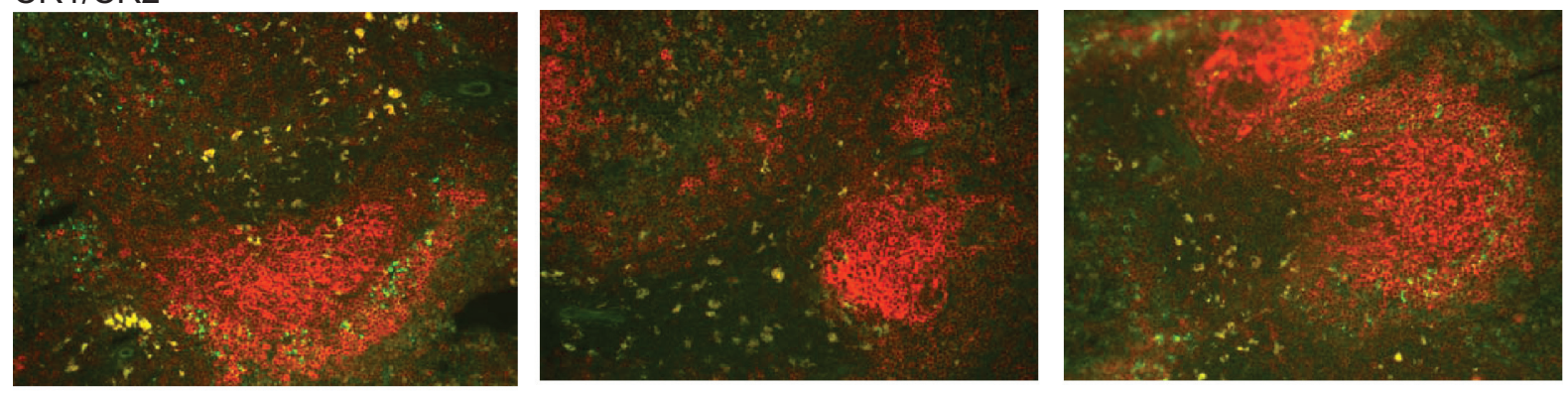

MARCO

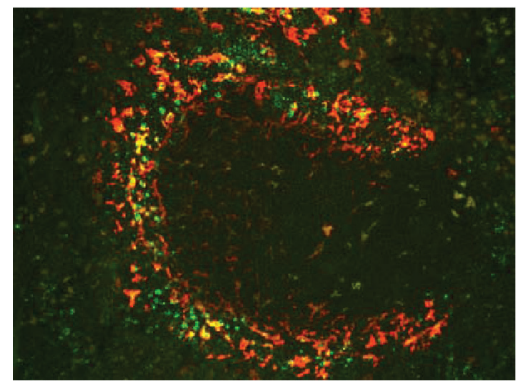

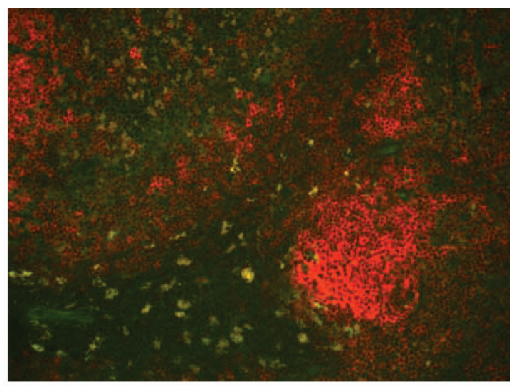

Cll peptide tetramer

2.4G2 scFv tetramer

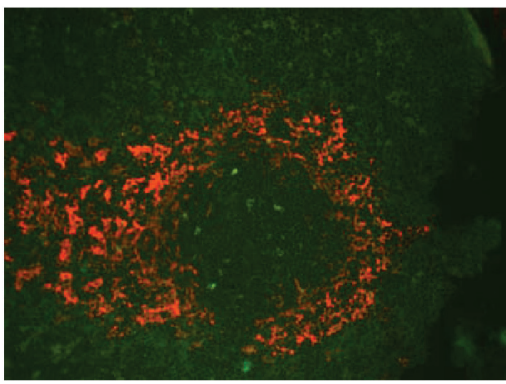

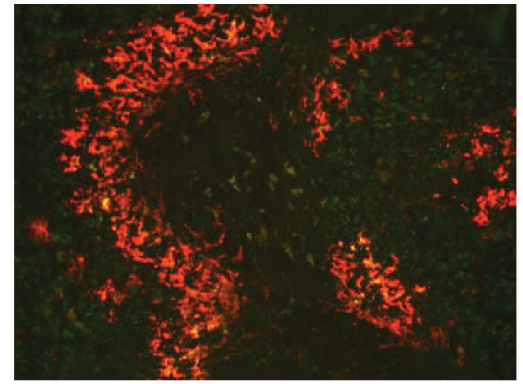

Figure 4 In vivo localization of 2.4G2 scFv-Cll-peptide complexes, Cll-peptide and 2.4G2 scFv tetramers in the spleen of collagen immunized DBA/I mice.

Notes: DBA/I mice were primed with collagen as described at Figure I. Extravidin-FITC containing complexes or tetramers were injected intravenously to collagen immunized DBA/I mice, then after I5 minutes spleens were collected, embedded and frozen. Sections of spleens were stained with complement receptor (CRI/CR2) specific antibody or with the marginal zone macrophage marker (MARCO). The complexes and tetramers are stained green, while the other markers are shown in red on the merged pictures at the same magnification. Overlap is visualized as yellow. Scale bar $=100 \mu \mathrm{m}$.

Abbreviations: CII, bovine type II collagen; FITC, fluorescein isothiocyanate; scFv, single chain Fv fragment.

performed on the pooled sera from each group of mice. The results were normalized to the values of the control group (suboptimally collagen immunized but otherwise untreated mice) (Figure 7). A highly elevated level of several cytokines and chemokines was detected in the sera of complex-treated mice as compared to the controls. The $2.4 \mathrm{G} 2 \mathrm{scFv}-\mathrm{CII}-$ peptide complexes induced the secretion of B lymphocyte chemoattractant (BLC/CXCL13), granulocyte colony stimulating factor (G-CSF), IL-1 $\alpha$, IL-3, IL-6, IL-7, IL-10, IL-12, IL-16, IL-17, IL-23, macrophage inflammatory protein 1 and 2 (MIP-1, MIP-2) and TNF $\alpha$. The level of IL-10 and MIP-2 (mouse equivalent of human IL-8) was estimated to be approximately 2500 times higher in complex-treated mice as compared to nontreated, collagen-immunized animals. Peptide tetramers triggered IL-10, IL-17, IL-23 and MIP-2 production, while $2.4 \mathrm{G} 2 \mathrm{scFv}$ tetramers crosslinking FcyRII/III triggered only G-CSF, IL-6, IL-10 and MIP-2 secretion in vivo (Figure 7). These data indicate that in accordance with their disease amplifying effect, both the FcyRII/III targeted CII peptide and CII-peptide tetramer stimulate the secretion of inflammatory cytokines, playing a crucial role in the initiation and maintenance of CIA..$^{36-39}$

\section{Discussion}

CIA is a useful model of RA for studying inflammation, autoimmunity and arthritis. Antibodies specific for collagen play a major role in the induction of the disease, and immune complexes formed by the autoantibodies contribute to inflammation and tissue destruction ${ }^{1,2,18,29}$ However, the mechanism of immune complex-mediated modulation of CIA is not fully understood. Our aim was to investigate the impact of Fc $\gamma$ RII/III targeted complexes composed of a collagen epitope peptide and $2.4 \mathrm{G} 2 \mathrm{scFv}$ on the induction and maintenance of CIA.

The CII-peptide was originally described as a triple helical conformational epitope of collagen spanning the 359-369 peptide region and was reported to be target for collagen specific antibodies of mice and for the sera of some RA patients. ${ }^{22,23}$ We hypothesized that the memory B-cells of collagen primed mice would recognize Fc $\gamma$ RII targeted CII-peptide, which in turn might switch off antibody production through the FcyRIIb dependent B-cell inhibition, thus ameliorating disease symptoms. Supplementary file 2 shows that indeed, $2.4 \mathrm{G} 2 \mathrm{scFv}$ is able to inhibit intracellular $\mathrm{Ca}^{2+}$ mobilization in B-cells when it is co-crosslinked 
IFN $\gamma$ production

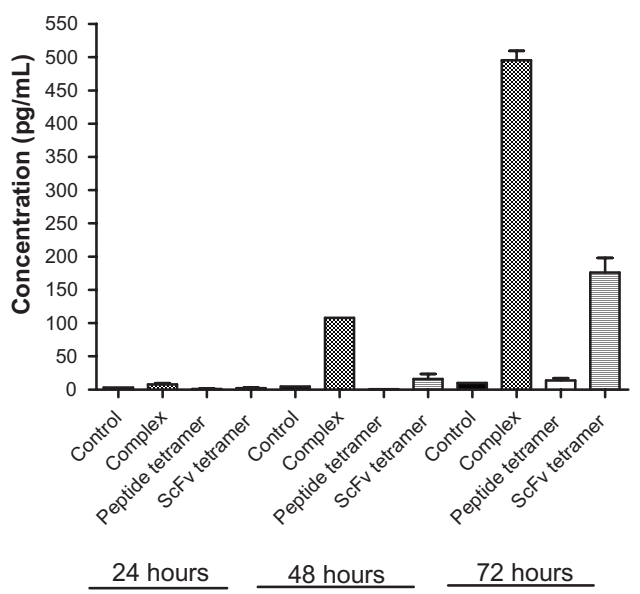

IL-10 production

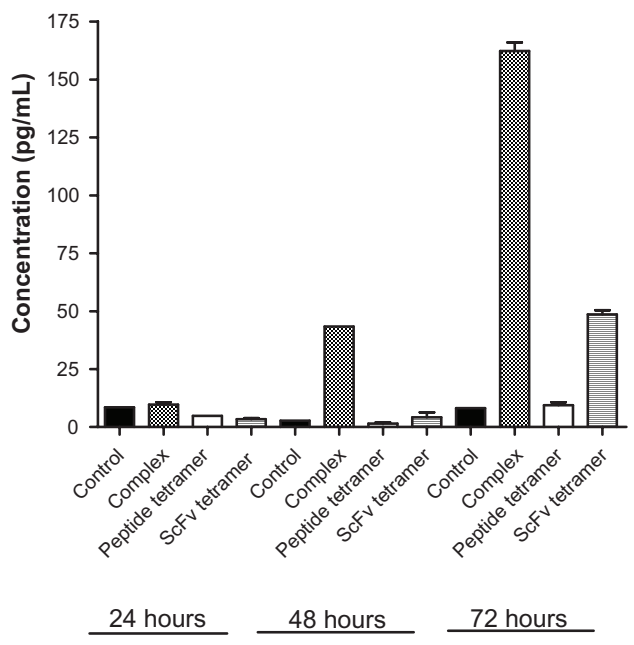

TNF $\alpha$ production

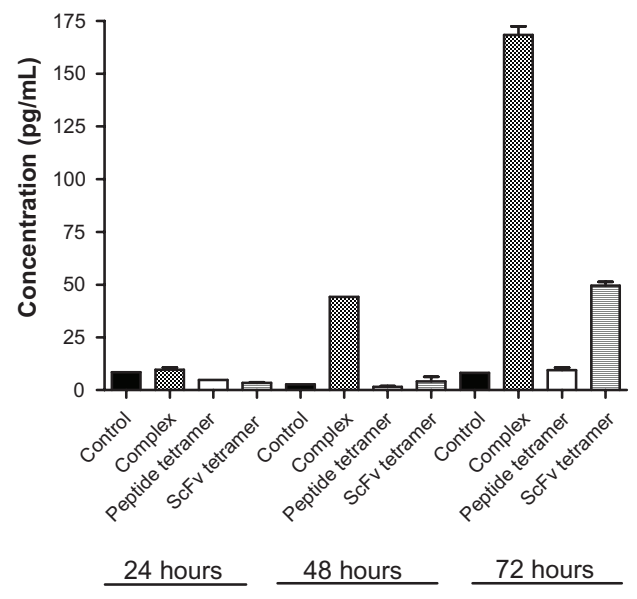

IL-17

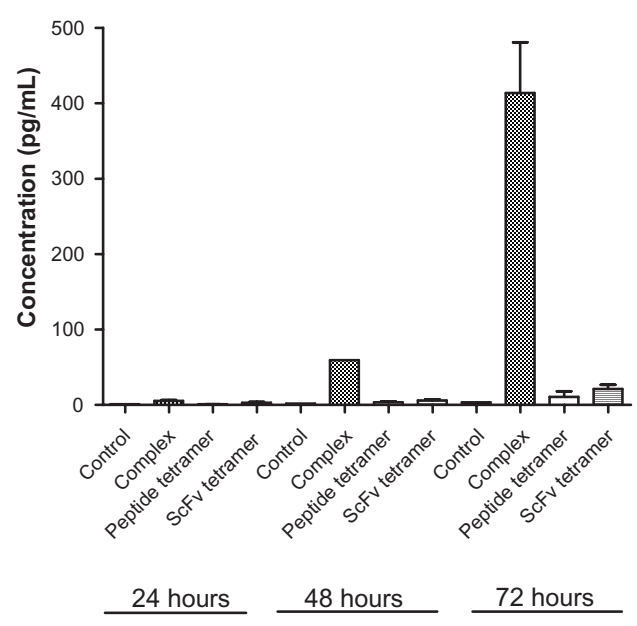

Figure 5 2.4G2 scFv-Cll-peptide complexes induce cytokine production in vitro.

Notes: Spleen cells of collagen immunized and then intravenously injected mice were cultured in the presence of the same constructs used for the in vivo boosting. Supernatants of spleen cell cultures were taken after 24, 48 and 72 hours, identical samples were pooled; then the amount of cytokine was determined by Quantikine ELISA kits. Abbreviations: CIl, bovine type II collagen; ELISA, enzyme-linked immunosorbent assay; scFv, single chain Fv fragment.

with BCR. However, we could not detect the binding of either 2.4G2 scFv or its complexes with CII-peptide to germinal center B-cells in spleen sections when they were applied in vivo.

Comparing CIA scores in the four experimental groups (suboptimally collagen immunized mice treated with 2.4G2 scFv-CII-peptide complexes, CII-peptide tetramers or $2.4 \mathrm{G} 2 \mathrm{scFv}$ tetramers), surprisingly we found that all molecular constructs elevated arthritic scores, thus significantly aggravating disease activity. By comparison, a mixture of monomeric CII-peptide and monomeric scFv did not elevate the arthritic scores as compared to controls. None of the constructs induced any sign of disease when administered into DBA/1 mice that were not immunized previously with collagen (data not shown). We assumed that the elevation of arthritic scores of collagen primed mice by Fc $\gamma$ RII/III targeted
CII-peptide and 2.4G2 scFv tetramers might be the result of targeting Fc $\gamma$ RII/III positive cells, ${ }^{24,25}$ including dendritic cells (DC) and macrophages.

To identify the type of cells that are able to bind the various complexes, we monitored their in vitro and in vivo binding to spleen cell subsets of collagen immunized DBA/1 mice. In vitro assays showed that approximately half of the spleen B-cells from collagen-immunized mice bound 2.4G2 scFvcontaining complexes or tetramers. This finding is in line with an earlier observation demonstrating that Fc $\gamma \mathrm{RIIb}$ expression is markedly downregulated in germinal center B-cells. ${ }^{40}$ The in situ analysis of the in vivo binding of intravenously injected 2.4G2 scFv-CII-peptide complexes showed that these preferentially bound to MARCO positive marginal zone macrophages, while a weaker reactivity of both the complexes and the peptide tetramers could also be observed with $\mathrm{CR} 1 / \mathrm{CR} 2^{\text {high }}$ cells. 

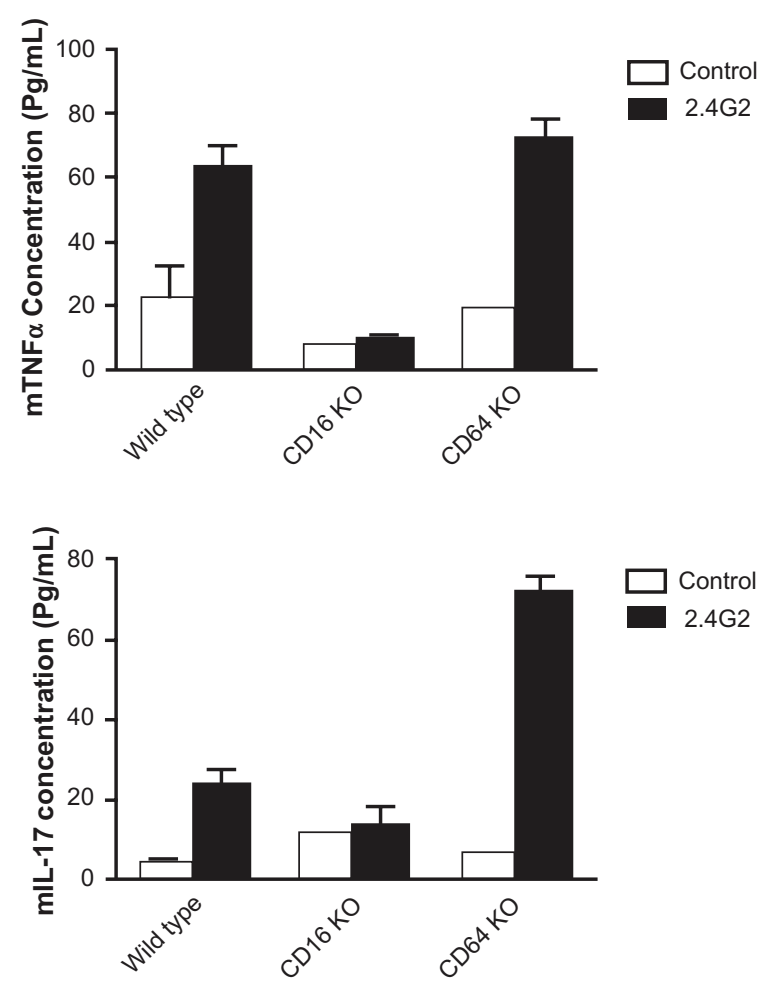

Figure 6 2.4G2 scFv tetramers induce TNF $\alpha$ and IL- 17 secretion in murine spleen cell cultures of wild type (C57/B16) and C64 KO but not of CDI6 KO mice. Notes: Plates were precoated with NeutrAvidin followed by biotinylated scFv of $2.4 \mathrm{G} 2$, then spleen cells from mice were seeded and incubated on this coat for 72 hours and the amount of cytokines was determined by Quantikine ELISA kits. Abbreviations: FITC, fluorescein isothiocyanate; ELISA, enzyme-linked immunosorbent assay; scFv, single chain Fv fragment; TNF $\alpha$, tumor necrosis factor alpha.

The T-zone location of these cells precludes their identification as follicular dendritic cells, but their morphology indicates some relatedness to DC-lineage. Flow cytometric analysis showed that about $40 \%$ of dendritic cells and more than half of the F4/80-positive macrophages bound 2.4G2 scFv-containing constructs ex vivo. Since the CII-peptide tetramers, besides binding to a small proportion of B-cells, also bound to macrophages and dendritic cells, we suppose that peptide-specific IgG in the serum of collagen primed mice mediates this binding (Figure 8). It was reported earlier that antigen complexed with specific IgG can be taken up by DCs in a nondegradative pathway via Fc $\gamma$ RIIb and subsequently re-expressed at the DC surface thus promoting B cell proliferation and IgG2a antibody production. ${ }^{41}$ Thus we assumed that $2.4 \mathrm{G} 2 \mathrm{scFv}$-CII-peptide complexes binding to FcyRIIb on DC promote the peptide specific IgG2a synthesis in the complex-treated mice.

To find out if CII-peptide-containing complexes and tetramers induce antibody synthesis, we compared the collagen-specific and the CII-peptide-specific IgG titers in the four experimental groups. Although administration of the various constructs into collagen-pre-immunized mice did not significantly modify the collagen-specific $\operatorname{IgG}$ titer, the Fc $\gamma \mathrm{RII} / \mathrm{III}$ targeted CII-peptide complexes significantly elevated the peptide-specific IgG titer as compared to the nontreated and tetramer treated groups. These data indicate that although CII-peptide specific IgG is present in the sera of all groups of collagen pre-immunized mice, Fc $\gamma$ RII/III targeted CII-peptide is significantly more efficient in eliciting peptidespecific antibody responses as compared to the CII-peptide alone. Serological data also demonstrated that the Fc $\gamma$ RII/III targeted CII-peptide complexes enhanced the synthesis of the inflammatory $\operatorname{IgG} 2$ a isotype, which is associated with a Th1 response. ${ }^{42}$ CII-peptide specific IgG2a in the serum would allow CII-peptide-IgG2a complexes to be formed in mice receiving CII-peptide containing constructs. IgG2a and IgG2b bind to stimulatory FcyRIV expressed by macrophages and neutrophils at 10-to-100-fold higher affinities compared to its inhibitory counterpart, Fc $\gamma \mathrm{RIIb}$, thus predicting that the production of these IgG subclasses could less effectively be blocked by Fc $\gamma$ RIIb-mediated suppression. ${ }^{43}$ Based on these findings, we suppose that CII-peptide-IgG2a complexes boost the inflammation in collagen primed DBA/ 1 mice due to their binding to Fc $\gamma$ RIV. This is in line with a recent report showing that the murine high-affinity IgG receptor Fc $\gamma R I V$ is sufficient for autoantibody-induced arthritis. ${ }^{44}$

The outcome of immune complex binding to Fc $\gamma R$ positive cells depends on the balance between activating and inhibiting Fc $\gamma R$. It was reported earlier that macrophages derived from CIA susceptible mice show a disregulated Fc $\gamma \mathrm{R}$ expression resulting in a prolonged expression of the activating Fc $\gamma R I$

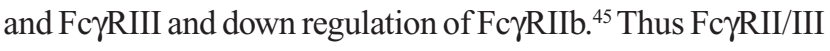
targeted CII-peptide complexes and tetramer $2.4 \mathrm{G} 2 \mathrm{scFv}$ may prominently bind to FcyRIII on macrophages in collagen primed DBA/1 mice, eliciting the production of proinflammatory cytokines such as IL-1 and TNF $\alpha .{ }^{21}$ Proinflammatory cytokines are important regulators of the synovial inflammation in RA. ${ }^{46}$ Th1 and Th17 cells producing IFN $\gamma$, IL-17 and IL-23 have been shown to aggravate RA, ${ }^{38}$ moreover, IL-17 together with TNF $\alpha$ was found to be predictive for poor outcome in RA. ${ }^{47}$ In CIA the IL-23/IL-17 axis is critical for the development of autoimmune arthritis. ${ }^{36}$ It was also shown that IL-17-deficient mice were resistant to CIA. ${ }^{48}$ Furthermore, IFN $\gamma$ and IL-17 amplified Fc $\gamma \mathrm{R}$ mediated cartilage destruction in murine immune complex-mediated arthritis. ${ }^{20} \mathrm{We}$ found that IFN $\gamma, \mathrm{TNF} \alpha, \mathrm{IL}-17$ and IL-10 were secreted in the in vitro culture of splenocytes of collagen preimmunized mice exposed to Fc $\gamma$ RII/III targeted CII-peptide complexes. Further, protein microarray analysis showed a substantial alteration in the secreted cytokine and chemokine profile two hours after injection of the complexes into collagen primed mice. A considerably increased level of 


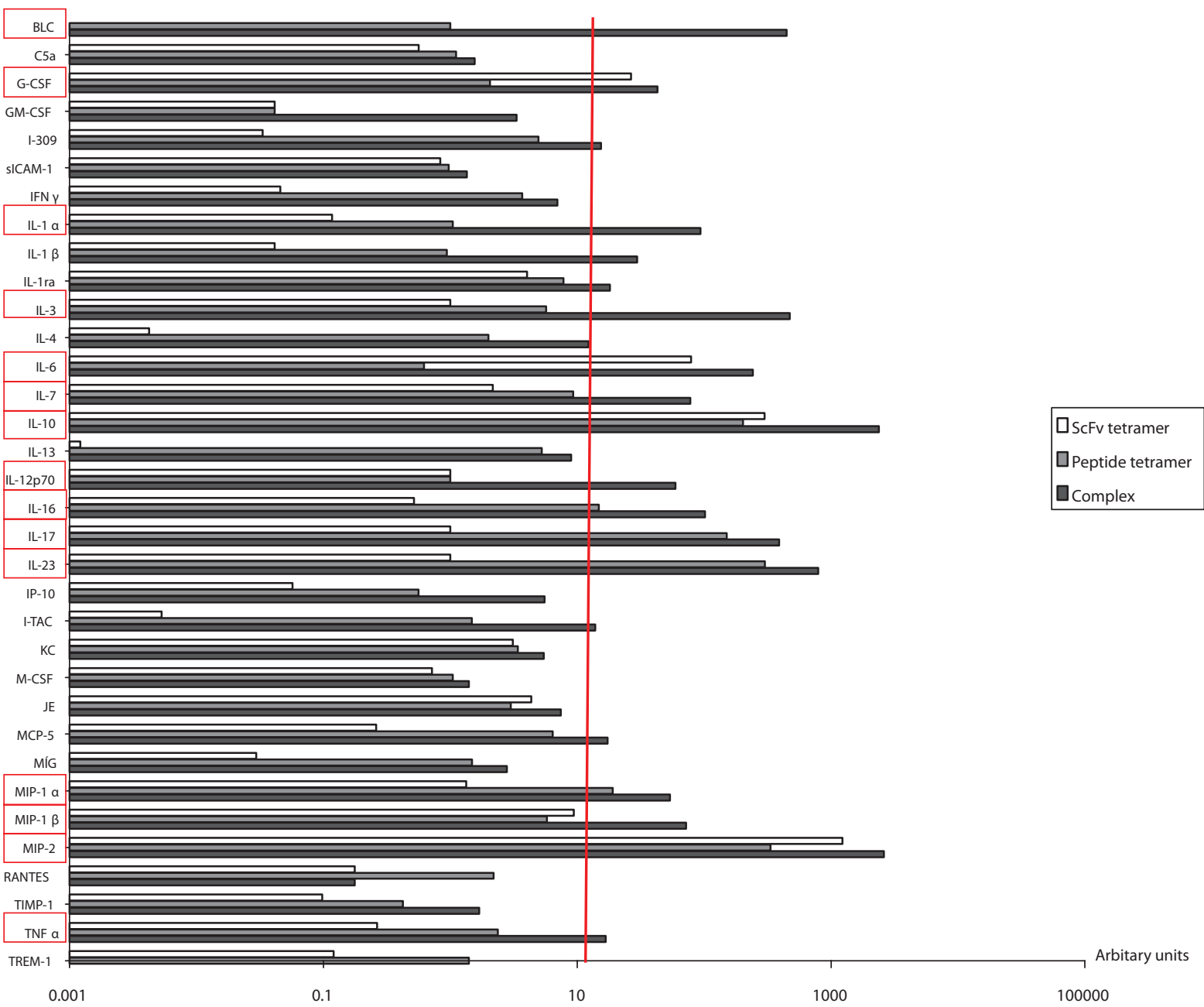

Figure 7 Chemokine/cytokine profile in sera of mice primed with collagen and then boosted intravenously with 2.4G2 scFv-CII-peptide complexes, or 'tetramer' Cll-peptide or $2.4 \mathrm{G} 2 \mathrm{scFv}$.

Notes: Serum samples were taken on day 70, 2 hours after the injection of $2.4 \mathrm{G} 2$ scFv tetramers (white bars), peptide tetramers (grey bars), or 2.4G2 scFv-CII-peptide complexes (dark bars), then cytokine and chemokine levels were determined by a protein microarray. Pixel densities of duplicate spots were compared. The results were normalized to values of collagen-immunized but nonboosted mice. The normalized values are shown as arbitrary units. The red line shows the threshold, where the values of boosted mice were 10 times that of the control, nonboosted mice. Above this value we considered the differences as substantial ones, as labeled on the left side by the red frame. A representative example of two independent experiments with pooled samples of sera from each group (4-7 mice/group) is shown.

Abbreviations: Cll, bovine type II collagen; scFv, single chain Fv fragment.

\section{IL-1, IL-3, IL-6, IL-7, IL-10, IL-12, IL-17, IL-23 and TNF $\alpha$} was detected and the secretion of chemokines CXCL13, MIP-1, and MIP-2 was also enhanced. CII-peptide tetramers stimulated IL-10, IL-17, IL-23, and MIP-2 production, while 2.4G2 tetramers that may crosslink the activating FcyRIII, enhanced G-CSF, IL-6, IL-10, and MIP-2 secretion.

Macrophage activation is induced by - among others - the action of immune complexes on activating Fc $\gamma \mathrm{R}$, triggering the production of a number of inflammatory mediators. ${ }^{49,50}$ Macrophage inflammatory protein $1 \alpha$ (MIP-1 $\alpha /$ CCL3) is produced by RA synovial tissue-lining cells and interstitial macrophages, ${ }^{51,52}$ and it is induced by TNF $\alpha .{ }^{49}$ MIP- $1 \alpha$ is chemotactic for monocytes, T, B and NK cells, basophils and eosinophils, and abundant MIP-1 $\alpha$ was found in RA synovial fluid..$^{53}$ Expression and contribution of MIP-1 $\alpha$ and macrophage inflammatory protein 2 (MIP-2) and also of IL-10 during the evolution of CIA has been described. IL-10 appears to be an important immunomodulator of the pathogenesis of CIA, regulating the expression of MIP- $1 \alpha$ and MIP-2. ${ }^{37}$ IL-23 produced by antigen-stimulated dendritic cells and macrophages is one of the essential factors required for the survival and/or expansion of Th17 cells, which produce IL-17, IL-17F, IL-6, and TNF $\alpha$. The IL-23/IL-17 axis also plays a key role in the development of autoimmune arthritis in humans. ${ }^{54} \mathrm{IL}-23$ acts on dendritic cells and macrophages in an autocrine/paracrine manner to stimulate the generation of proinflammatory cytokines, such as IL-1, IL- 6 , and TNF- $\alpha$ in autoimmune inflammatory diseases. ${ }^{36} \mathrm{~A} 2$-year study on a 


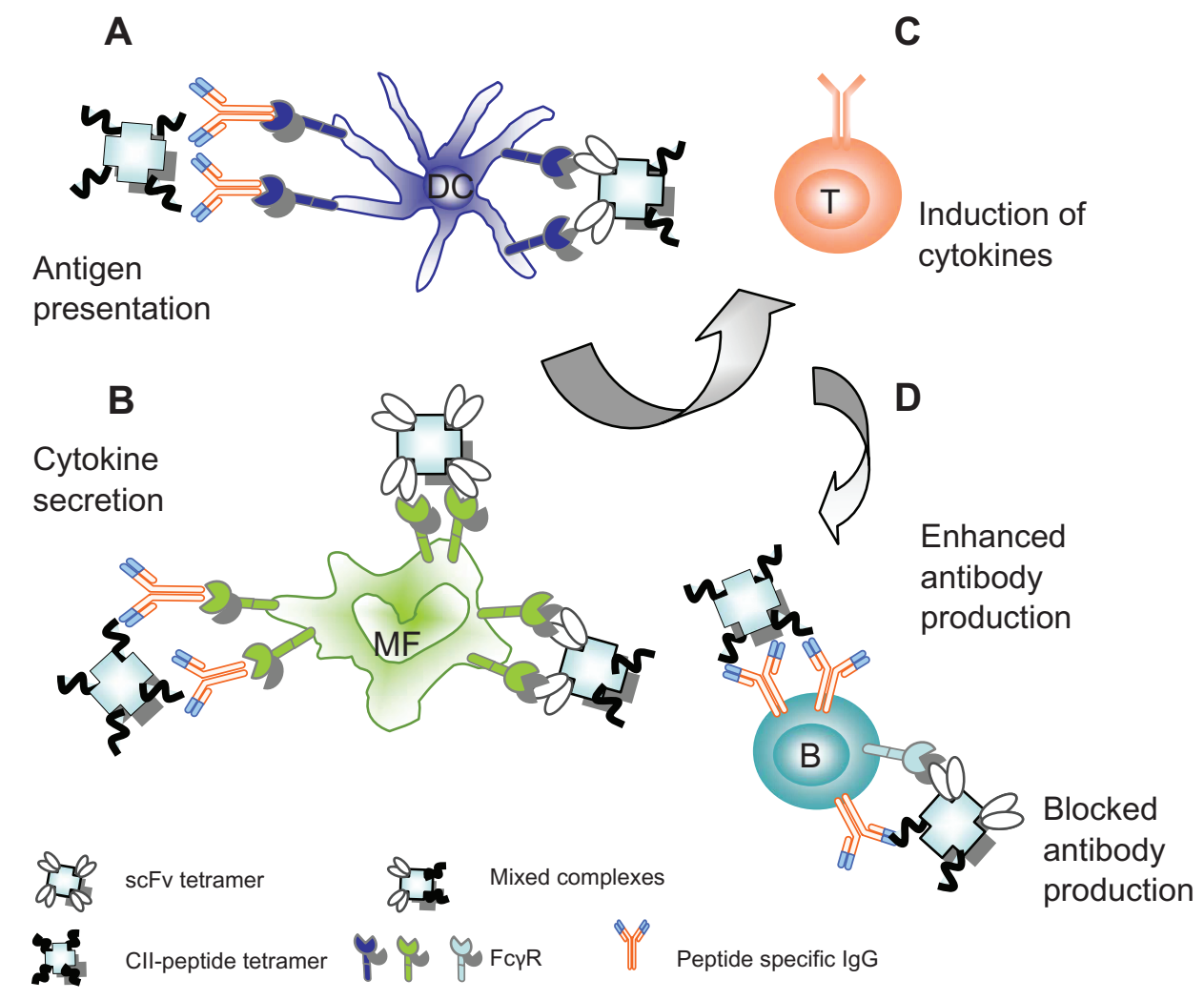

Figure 8 Possible ways to regulate ClA by complexes targeted to FcyR. (A) On dendritic cells: mixed complexes of $2.4 \mathrm{G} 2$ scFv and Cll-peptide or tetramers of Cllpeptides may directly or indirectly, via peptide-specific lgG, bind to FcyRII/III, thus enhancing the antigen presentation. (B) On macrophages: $2.4 \mathrm{G} 2$ scFv tetramers and mixed complexes or Cll-peptide tetramers may directly or indirectly, via the bound peptide-specific IgG2a, crosslink Fc $\gamma \mathrm{RII/III}$ or Fc $\gamma \mathrm{RIV}$, thereby inducing cytokine release. (C) Cytokines such as IL-12 or IL-23 produced by DC and macrophages in response to the complexes may induce THI cells to produce IFN $\gamma$ and other cytokines inducing the inflammatory THI response. (D) On B-cells: the mixed complexes may simultaneously bind via BCR and the inhibitory FcyRllb, cross-linking the receptors and block antibody synthesis; alternatively, binding to BCR alone Cll-peptide tetramers may facilitate the Cll-peptide specific immune response.

Abbreviations: CIl, bovine type II collagen; CIA, collagen-induced arthritis; scFv, single chain Fv fragment.

cohort of RA patients has demonstrated that synovial membrane mRNA levels of IL-1beta, TNF- $\alpha$, IL-17, and IL-10 were predictive of damage progression. IL-17 was synergistic with TNF- $\alpha .{ }^{47}$ The synovial milieu in established RA contains various macrophage- and synovial-fibroblast derived cytokines, such as IL-1 $\beta$, IL-6, IL-7, IL-12, IL-15, IL-18, IL-23p19, and TGF $\beta$ that can support the expansion and differentiation of Th1 and/or Th17 cells. ${ }^{49}$ Bone resorption in RA is induced by osteoclasts, and osteoclast differentiation is achieved by the actions of TNF and IL-1, as well as of IL-17, produced by Th17 cells, and IL-7, produced by synovial fibroblasts. ${ }^{49}$ These data show that evidence suggesting rheumatoid arthritis as a primarily Th17-/IL-17-dependent autoimmune inflammatory disease is rapidly accumulating.

Taken together, our data suggest that 2.4G2 scFv-CIIpeptide complexes and the in vivo formed IgG2a-CII-peptide immune complexes may bind to Fc $\gamma \mathrm{RIII}$ and/or to Fc $\gamma \mathrm{RIV}$, inducing the secretion of IL-23 from dendritic cells and macrophages, which in turn triggers Th17 cells to secrete IL-17, IL-6 and TNF $\alpha$. Additionally, the enhanced production of further inflammatory cytokines and chemokines was detected after the intravenous injection of the complexes and tetramers. Treatment of collagen preimmunized DBA/1 mice with the FcyRII/III targeted complexes also resulted in increased secretion of IL-3 and G-CSF. Recent data indicate that IL-3 produced by CD4+T-cells in the presence of CD11b+ macrophages has an important role in the early phase of CIA by activating basophils, thus considerably expanding the range of possible effector cells. ${ }^{55}$ Furthermore, it was reported that daily injections of M-CSF or G-CSF, 20-24 days after primary immunization with type II collagen, exacerbate disease symptoms in suboptimally immunized DBA/1 mice, showing that $\mathrm{M}-\mathrm{CSF}$ and G-CSF can be proinflammatory in CIA. ${ }^{56}$ Among the chemokines induced by the FcyRII/III targeted CII-peptide complexes BLC (CXCL13), MIP1 and MIP-2 are the most important. B lymphocyte chemoattractant cytokine CXCL13 controls follicle formation and may facilitate ectopic lymphoid organogenesis in the synovium and the local production of tissue-specific auto-antibody. ${ }^{57}$ CXCL13 is expressed in the synovial tissue of RA patients and its blockade reduces the 
severity of CIA, indicating that CXCL13 plays an important role in the development and pathogenesis of the disease. ${ }^{58}$

\section{Conclusions}

Taken together, these data indicate that the administration of Fc $\gamma \mathrm{RII} / \mathrm{III}$ targeted CII-peptide complexes into collagen primed DBA/1 mice enhances the inflammatory TH1 driven IgG2a response to CII-peptide and stimulates inflammatory cytokine and chemokine production. Boosting the mice with CII-peptide tetramers after primary immunization with collagen may result in the formation of CII-peptideIgG2a complexes. These complexes may bind to Fc $\gamma \mathrm{RIV}$, while $2.4 \mathrm{G} 2 \mathrm{scFv}$ containing complexes bind to Fc $\gamma \mathrm{RIII}$; both enhancing the secretion of potent pro-inflammatory mediators such as IL-23 and MIP-2, playing a key role in autoimmune arthritis (Figure 8). We identified in this study the cytokines and chemokines, the production of which is stimulated by complexes binding to activating Fc $\gamma \mathrm{R}$, which might be the targets of future therapies.

\section{Abbreviations}

BLC, B lymphocyte chemoattractant; CII, bovine type II collagen; CIA, collagen-induced arthritis; CR, complement receptors; Fc $\gamma R$, Fcgamma receptors; FITC, fluorescein isothiocyanate; G-CSF, granulocyte colony stimulating factor; IFN, interferon; MARCO, Macrophage Receptor with Collagenous structure; MIP, Macrophage Inflammatory Protein; RA, rheumatoid arthritis; scFv, single chain Fv fragment; TNF, tumor necrosis factor.

\section{Funding}

This work was supported by the Hungarian Scientific Research Fund and the National Development Agency (OTKA 60760, OTKA K 68617, OTKA NI 68466, OTKA CK 80689). The European Union and the European Social Fund have provided financial support to the project under the grant agreement no. TÁMOP 4.2.1./B-09/1/KMR-20100003. D. Kövesdi currently is a Magyary Zoltan Postdoctoral Fellow; the Fellowship is supported by the EEA Grants and Norway Grants.

\section{Acknowledgments}

The authors would like to thank Dr Anna Magyar, Research Group of Peptide Chemistry, Office for Research Groups Attached to Universities and Other Institutions of the Hungarian Academy of Sciences, for the synthesis of the biotinylated collagen peptide. The authors thank Arpad Mikesy for taking care of the mice.

\section{Disclosure}

The authors report no conflicts of interest in this work.

\section{References}

1. Courtenay JS, Dallman MJ, Dayan AD, Martin A, Mosedale B. Immunisation against heterologous type II collagen induces arthritis in mice. Nature. 1980;283(5748):666-668.

2. Stuart JM, Dixon FJ. Serum transfer of collagen-induced arthritis in mice. J Exp Med. 1983;158(2):378-392.

3. Nandakumar KS, Andren M, Martinsson P, et al. Induction of arthritis by single monoclonal IgG anti-collagen type II antibodies and enhancement of arthritis in mice lacking inhibitory FcgammaRIIB. Eur J Immunol. 2003;33(8):2269-2277.

4. Nandakumar KS, Svensson L, Holmdahl R. Collagen type II-specific monoclonal antibody-induced arthritis in mice: description of the disease and the influence of age, sex, and genes. Am J Pathol. 2003;163(5): $1827-1837$.

5. Rowley MJ, Nandakumar KS, Holmdahl R. The role of collagen antibodies in mediating arthritis. Mod Rheumatol. 2008;18(5):429-441.

6. Nimmerjahn F, Bruhns P, Horiuchi K, Ravetch JV. FcgammaRIV: a novel FcR with distinct IgG subclass specificity. Immunity. 2005;23(1):41-51.

7. Ravetch JV, Bolland S. IgG Fc receptors. Annu Rev Immunol. 2001;19: 275-290.

8. Cambier JC. Antigen and Fc receptor signaling. The awesome power of the immunoreceptor tyrosine-based activation motif (ITAM). J Immunol. 1995;155(7):3281-3285.

9. Daeron M. Structural bases of Fc gamma R functions. Int Rev Immunol. 1997;16(1-2):1-27.

10. Takai T. Roles of Fe receptors in autoimmunity. Nat Rev Immunol. 2002;2(8):580-592.

11. Daeron M, Latour S, Malbec O, et al. The same tyrosine-based inhibition motif, in the intracytoplasmic domain of $\mathrm{Fc}$ gamma RIIB, regulates negatively BCR-, TCR-, and FcR-dependent cell activation. Immunity. 1995;3(5):635-646.

12. Isakov N. ITIMs and ITAMs. The Yin and Yang of antigen and Fc receptor-linked signaling machinery. Immunol Res. 1997;16(1):85-100.

13. Takai T. Multiple loss of effector cell functions in FcR gamma-deficient mice. Int Rev Immunol. 1996;13(4):369-381.

14. Clynes R, Maizes JS, Guinamard R, Ono M, Takai T, Ravetch JV. Modulation of immune complex-induced inflammation in vivo by the coordinate expression of activation and inhibitory Fc receptors. $J$ Exp Med. 1999;189(1):179-185.

15. Nakamura A, Yuasa T, Ujike A, et al. Fcgamma receptor IIB-deficient mice develop Goodpasture's syndrome upon immunization with type IV collagen: a novel murine model for autoimmune glomerular basement membrane disease. J Exp Med. 2000;191(5):899-906.

16. Nimmerjahn F, Ravetch JV. Fcgamma receptors as regulators of immune responses. Nat Rev Immunol. 2008;8(1):34-47.

17. Kleinau S, Martinsson P, Heyman B. Induction and suppression of collagen-induced arthritis is dependent on distinct fcgamma receptors. J Exp Med. 2000;191(9):1611-1616.

18. Magnusson SE, Andren M, Nilsson KE, Sondermann P, Jacob U, Kleinau S. Amelioration of collagen-induced arthritis by human recombinant soluble FcgammaRIIb. Clin Immunol. 2008;127(2):225-233.

19. Boross P, van Lent PL, Martin-Ramirez J, et al. Destructive arthritis in the absence of both FcgammaRI and FcgammaRIII. J Immunol. 2008; 180(7):5083-5091.

20. Grevers LC, van Lent PL, Koenders MI, et al. Different amplifying mechanisms of interleukin-17 and interferon-gamma in Fcgamma receptor-mediated cartilage destruction in murine immune complexmediated arthritis. Arthritis Rheum. 2009;60(2):396-407.

21. Abrahams VM, Cambridge G, Lydyard PM, Edwards JC. Induction of tumor necrosis factor alpha production by adhered human monocytes: a key role for Fcgamma receptor type IIIa in rheumatoid arthritis. Arthritis Rheum. 2000;43(3):608-616. 
22. Burkhardt H, Koller T, Engstrom A, et al. Epitope-specific recognition of type II collagen by rheumatoid arthritis antibodies is shared with recognition by antibodies that are arthritogenic in collagen-induced arthritis in the mouse. Arthritis Rheum. 2002;46(9):2339-2348.

23. Schulte $\mathrm{S}$, Unger $\mathrm{C}, \mathrm{Mo} J \mathrm{~A}$, et al. Arthritis-related B cell epitopes in collagen II are conformation-dependent and sterically privileged in accessible sites of cartilage collagen fibrils. J Biol Chem. 1998;273(3):1551-1561.

24. Angyal A, Szekeres Z, Balogh P, et al. CD16/32-specific biotinylated 2.4G2 single-chain Fv complexed with avidin-FITC enhances FITCspecific humoral immune response in vivo in a CD16-dependent manner. Int Immunol. 2010;22(2):71-80.

25. Szekeres Z, Herbath M, Angyal A, et al. Modulation of immune response by combined targeting of complement receptors and low-affinity Fcgamma receptors. Immunol Lett. 2010;130(1-2):66-73.

26. Kvell K, Czompoly T, Pikkarainen T, Balogh P. Species-specific restriction of cell surface expression of mouse MARCO glycoprotein in murine cell lines. Biochem Biophys Res Commun. 2006;341(4):1193-1202.

27. Hazenbos WL, Gessner JE, Hofhuis FM, et al. Impaired IgG-dependent anaphylaxis and Arthus reaction in Fc gamma RIII (CD16) deficient mice. Immunity. 1996;5(2):181-188.

28. Ioan-Facsinay A, de Kimpe SJ, Hellwig SM, et al. FcgammaRI (CD64) contributes substantially to severity of arthritis, hypersensitivity responses, and protection from bacterial infection. Immunity. 2002;16(3):391-402.

29. Wooley PH, Luthra HS, Stuart JM, David CS. Type II collagen-induced arthritis in mice. I. Major histocompatibility complex (I region) linkage and antibody correlates. $J$ Exp Med. 1981;154(3):688-700.

30. Kurucz I, Titus JA, Jost CR, Segal DM. Correct disulfide pairing and efficient refolding of detergent-solubilized single-chain Fv proteins from bacterial inclusion bodies. Mol Immunol. 1995;32(17-18):1443-1452.

31. Unkeless JC, Fleit H, Mellman IS. Structural Aspects and Heterogeneity of Immunoglobulin Fc Receptors. Adv Immunol. 1981;31:247-270.

32. Chapman-Smith A, Cronan JE Jr. The enzymatic biotinylation of proteins: a post-translational modification of exceptional specificity. Trends Biochem Sci. 1999;24(9):359-363.

33. O'Callaghan CA, Byford MF, Wyer JR, et al. BirA enzyme: production and application in the study of membrane receptor-ligand interactions by site-specific biotinylation. Anal Biochem. 1999;266(1):9-15.

34. Svensson HG, Hoogenboom HR, Sjobring U. Protein LA, a novel hybrid protein with unique single-chain Fv antibody- and Fab-binding properties. Eur J Biochem. 1998;258(2):890-896.

35. van den Berg TK, Kraal G. A function for the macrophage F4/80 molecule in tolerance induction. Trends Immunol. 2005;26(10):506-509.

36. Iwakura Y, Ishigame H. The IL-23/IL-17 axis in inflammation. J Clin Invest. 2006;116(5):1218-1222.

37. Kasama T, Strieter RM, Lukacs NW, Lincoln PM, Burdick MD, Kunkel SL. Interleukin-10 expression and chemokine regulation during the evolution of murine type II collagen-induced arthritis. J Clin Invest. 1995;95(6):2868-2876.

38. Lubberts E. Th17 cytokines and arthritis. Semin Immunopathol. 2010; 32(1):43-53.

39. Murphy CA, Langrish CL, Chen Y, et al. Divergent pro- and antiinflammatory roles for IL-23 and IL-12 in joint autoimmune inflammation. J Exp Med. 2003;198(12):1951-1957.

40. Rao SP, Vora KA, Manser T. Differential expression of the inhibitory IgG Fc receptor FcgammaRIIB on germinal center cells: implications for selection of high-affinity B cells. J Immunol. 2002;169(4):1859-1868.
41. Hauser AE, Kerfoot SM, Haberman AM. Cellular choreography in the germinal center: new visions from in vivo imaging. Semin Immunopathol. 2010;32(3):239-255.

42. Mukherjee P, Wu B, Mayton L, Kim SH, Robbins PD, Wooley PH. TNF receptor gene therapy results in suppression of IgG2a anticollagen antibody in collagen induced arthritis. Ann Rheum Dis. 2003;62(8): 707-714.

43. Nimmerjahn F, Ravetch JV. Fcgamma receptors: old friends and new family members. Immunity. 2006;24(1):19-28.

44. Mancardi DA, Jonsson F, Iannascoli B, et al. The murine high-affinity IgG receptor FcgammaRIV is sufficient for autoantibody-induced arthritis. J Immunol. 186(4):1899-1903.

45. Blom AB, van Lent PL, Holthuysen AE, Jacobs C, van den Berg WB. Skewed balance in basal expression and regulation of activating $\mathrm{v}$ inhibitory Fcgamma receptors in macrophages of collagen induced arthritis sensitive mice. Ann Rheum Dis. 2003;62(5):465-471.

46. Arend WP, Dayer JM. Inhibition of the production and effects of interleukin-1 and tumor necrosis factor alpha in rheumatoid arthritis. Arthritis Rheum. 1995;38(2):151-160.

47. Kirkham BW, Lassere MN, Edmonds JP, et al. Synovial membrane cytokine expression is predictive of joint damage progression in rheumatoid arthritis: a two-year prospective study (the DAMAGE study cohort). Arthritis Rheum. 2006;54(4):1122-1131.

48. Nakae S, Nambu A, Sudo K, Iwakura Y. Suppression of immune induction of collagen-induced arthritis in IL-17-deficient mice. J Immunol. 2003;171(11):6173-6177.

49. McInnes IB, Schett G. Cytokines in the pathogenesis of rheumatoid arthritis. Nat Rev Immunol. 2007;7(6):429-442.

50. Szekanecz Z, Kim J, Koch AE. Chemokines and chemokine receptors in rheumatoid arthritis. Semin Immunol. 2003;15(1):15-21.

51. Koch AE. Chemokines and their receptors in rheumatoid arthritis: future targets? Arthritis Rheum. 2005;52(3):710-721.

52. Szekanecz Z, Koch AE. Chemokines and angiogenesis. Curr Opin Rheumatol. 2001;13(3):202-208.

53. Koch AE, Kunkel SL, Harlow LA, et al. Macrophage inflammatory protein-1 alpha. A novel chemotactic cytokine for macrophages in rheumatoid arthritis. J Clin Invest. 1994;93(3):921-928.

54. Paradowska-Gorycka A, Grzybowska-Kowalczyk A, Wojtecka-Lukasik E, Maslinski S. IL-23 in the pathogenesis of rheumatoid arthritis. Scand J Immunol. 71(3):134-145.

55. Bruhl H, Cihak J, Niedermeier M, et al. Important role of interleukin-3 in the early phase of collagen-induced arthritis. Arthritis Rheum. 2009; 60(5):1352-1361.

56. Campbell IK, Rich MJ, Bischof RJ, Hamilton JA. The colonystimulating factors and collagen-induced arthritis: exacerbation of disease by M-CSF and G-CSF and requirement for endogenous M-CSF. J Leukoc Biol. 2000;68(1):144-150.

57. Legler DF, Loetscher M, Roos RS, Clark-Lewis I, Baggiolini M, Moser B. B cell-attracting chemokine 1, a human CXC chemokine expressed in lymphoid tissues, selectively attracts B lymphocytes via BLR1/CXCR5. J Exp Med. 1998;187(4):655-660.

58. Zheng B, Ozen Z, Zhang X, et al. CXCL13 neutralization reduces the severity of collagen-induced arthritis. Arthritis Rheum. 2005;52(2): $620-626$. 


\section{Supplementary figures}

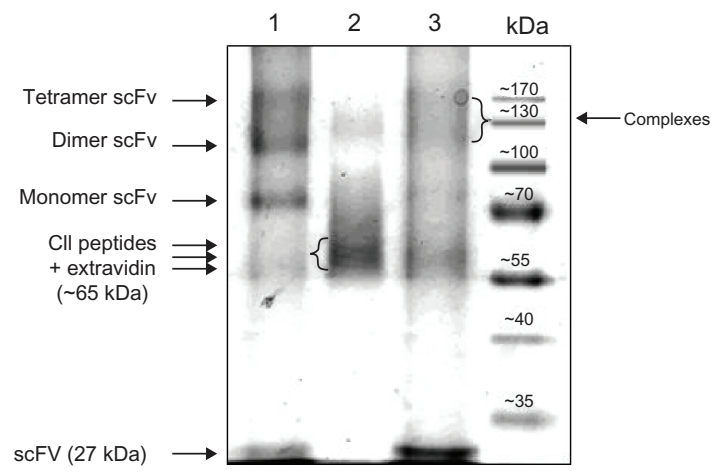

Figure SI Composition of the extravidin bound 2.4G2 scFv, Cll-peptide and Cll-peptide $-2.4 \mathrm{G} 2 \mathrm{scFv}$ mixed complexes resolved by non-reducing SDS-PAGE.

Notes: Lane I: $2.4 \mathrm{G} 2 \mathrm{scFv}$ 'tetramer': $60 \mu \mathrm{g}$ biotinylated $2.4 \mathrm{G} 2 \mathrm{scFv}$ and $30 \mu \mathrm{g}$ extravidin were mixed (4:I molar ratio), lane 2: 'Cll-peptide 'tetramer': $2.6 \mu \mathrm{g}$ biotinylated Cll-peptide (ARGLTGRPGDA) was mixed with $30 \mu \mathrm{g}$ Extravidin (4:I molar ratio), lane 3: preformed complexes of $60 \mu \mathrm{g}$ biotinylated $2.4 \mathrm{G} 2 \mathrm{scFv}, 2.6 \mu \mathrm{g}$ biotinylated collagen peptide (Cll-peptide) and $60 \mu \mathrm{g}$ extravidin (2:2:I molar ratio). Arrows show the position of various size of scFv-extravidin complexes (lane I) or Cll-peptide-extravidin complexes (lane 2), or the mixed complexes (lane 3). The band around $60 \mathrm{kD}$ corresponds to extravidin.

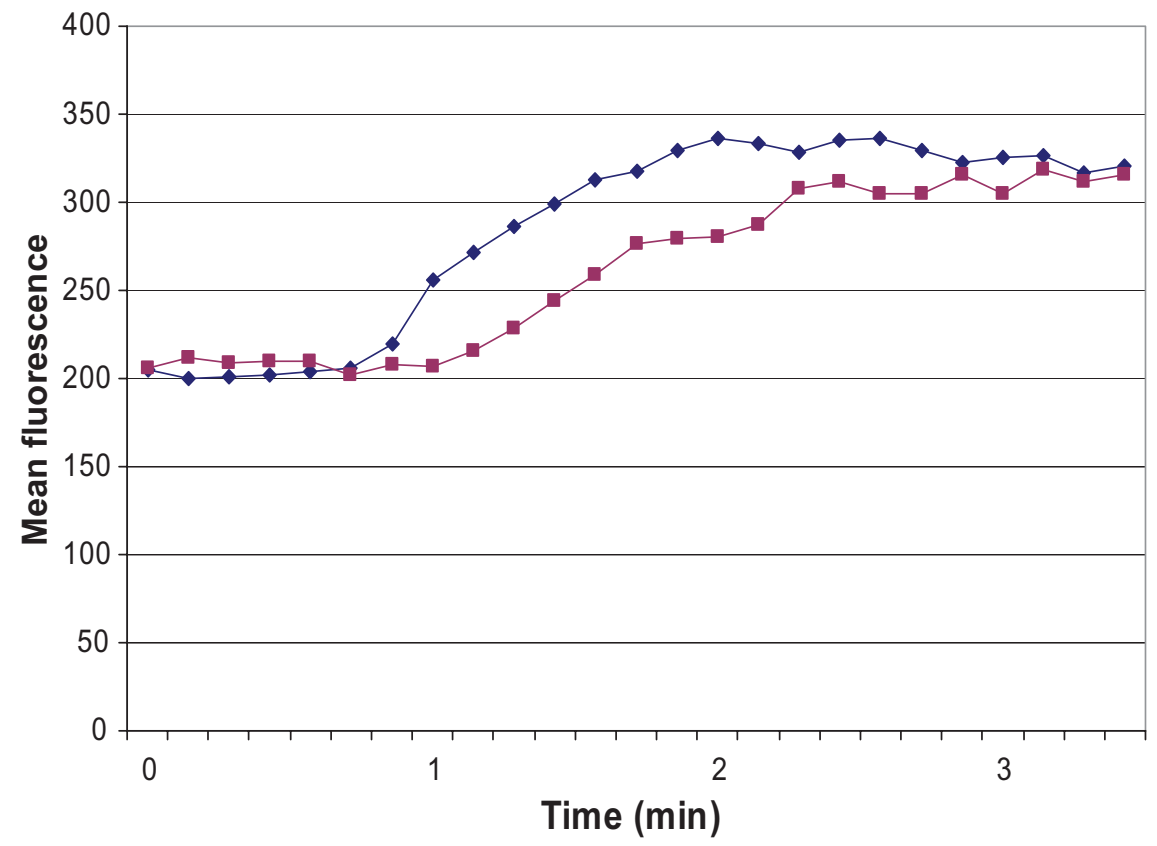

Figure S2 2.4G2 scFv inhibits intracellular rise of free $\mathrm{Ca}^{2+}$ when Fc $\gamma R \mathrm{Rllb}$ and $\mathrm{BCR}$ are co-crosslinked.

Notes: Cells were loaded with $5 \mathrm{mM}$ fluo-3/AM indicator and $30 \mathrm{mg} / \mathrm{mL}$ Pluronic F- 127 for $30 \mathrm{~min}$ at $37^{\circ} \mathrm{C}$ in I mL medium. The cells were diluted I0 times and incubated for another $30 \mathrm{~min}$ at $37^{\circ} \mathrm{C}$, then washed, resuspended and labeled with 7-AAD to exclude the dead cells. All studies were carried out in RPMI I640 culture medium. Spleen B-cells were treated with: $0.2 \mu \mathrm{g}$ protein LA $+0.2 \mu \mathrm{g}$ avidin for BCR crosslinking (blue line), and I0 $\mu \mathrm{g} 2.4 \mathrm{G} 2 \mathrm{scFv}-\mathrm{b}+0.2 \mu \mathrm{g}$ protein LA + $0.2 \mu \mathrm{g}$ avidin for BCR-Fc $\gamma R$ Illb co-crosslinking (purple line). Protein LA is a hybrid protein recognizing Ig kappa chain, and scFv (Eur J Biochem. December I, 1998;258(2):890-896.). Kinetics of the change of mean fluorescence are shown, as calculated by Lysys II software (Becton Dickinson, San Jose, CA).

\section{Publish your work in this journal}

Biologics: Targets \& Therapy is an international, peer-reviewed journal focusing on the patho-physiological rationale for and clinical application of Biologic agents in the management of autoimmune diseases, cancers or other pathologies where a molecular target can be identified. This journal is indexed on PubMed Central, CAS, EMBase, Scopus

\section{Dovepress}

and the Elsevier Bibliographic databases. The manuscript management system is completely online and includes a very quick and fair peerreview system, which is all easy to use. Visit http://www.dovepress. com/testimonials.php to read real quotes from published authors. 